\title{
Multimedia Learning Design for Ablution and Prayer (Case Studies at Pesantren Arafah Kota Sungai Penuh)
}

\author{
Sotar $^{1}$, Suardinata*, Randi Satia Irawan ${ }^{3}$ \\ ${ }^{1}$ STMIK Indonesia Padang, Dept. Information System \\ J1 Khatib Sulaiman Dalam No 1 Padang, Indonesia \\ ${ }^{2}$ STMIK Indonesia Padang, Dept. Information System \\ J1 Khatib Sulaiman Dalam No 1 Padang, Indonesia \\ ${ }^{3}$ STMIK Indonesia Padang, Dept. Information System \\ Jl Khatib Sulaiman Dalam No 1 Padang, Indonesia
}

\begin{abstract}
:
Pesantren Arafah Kota Sungai Penuh is a boarding school attached to Islamization, where every student is required to be able to perform the prayer properly and correctly. With the current teaching-learning process, while teacher still using gestures or still using whiteboards and markers as a medium of learning, so students tend to get bored and difficult to understand, memorize and learn that is taught by the teacher. This research was conducted to make the application related to the obligatory multimedia-based prayer guidance, so that students are easier to remember, understand and study the prayer guidance. The methods used in making this application include; analyze the problem, make designing, make the application program using Macomedia flash 8 software ends by testing. This app consists of three most important parts. First, the input contains the data required in this application. Second, the file that serves as a liaison between the flash and then the data will be displayed into the flash. And third, is making the application on flash as the end of this application. From the results of application testing mandatory prayer-based multimedia can be obtained that by using this application students learn more easily to understand a material. With the construction of multimedia-based applications is expected to increase student motivation in learning and can be easy to memorize, understand and study the mandatory prayer guidance.
\end{abstract}

Keywords: System, Learning, Guidance, Prayer, Ablution, Multimedia

\section{Introduction}

Utilization of computers evolved from the realm of business to the domestic realm, computers have become a necessity and not foreign goods anymore. Computers not only work for the office only, but serves as a simulation tool, information systems and even for special purposes, do not miss the field of learning children have been touched by computerization (Fachrurrazi \& Afwadi, 2010) Learning is how to gain insight on various topics and issues and develop an understanding of learning. Matz (2010)

In the world of education today, the various methods and techniques used in learning as many researchers say, as likes lectures, discussions, the use of multimedia, practical examples relative emphasis on the use of modern technology, they further discuss that contemporary teaching methods are very useful to help students of science and mathematics as proposed by Liu et al (2009). The development of education today is not separated from the development of science and computer technology, therefore the world of education is required to always move to follow the development of global technology. Today, with the rapid development of computers is able to change the ways and methods used by teachers in learning in school. One of the computer technologies is again the current trend is multimedia technology, where multimedia becomes a trend in the world of education today (Lubis et al., 2013). This technology has previously been created and applied to the education world in developed countries, such as neighboring countries, Malaysia, Pakistan, Brunei and also other countries. 
In Islamic learning, this technology has been widely used as a tool and medium of learning in Islamic studies in primary and secondary schools. With multimedia technology is very helpful for a teacher in the process of teaching and learning in the classroom such as how to perform proper ablution, how to read hijaiyah letters, how to pray, how to improve the ability of early childhood and other prayers.

As a multimedia technology created by Nora M, 2008 was created a project, where this technology is made and is intended for children aged 6-12 years in order to perform prayers in the correct order. While other researcher (Hidayati, 2012) have also created a modeling method that as known multimedia technology, where this technology is devoted to improve the ability of early childhood prayer.

In Indonesia today in general, schools and boarding schools using learning media are still traditional and conventional. As many studies have been done by researchers so far still have an unfavorable impact on student learning outcomes. As mentioned (Hidayati, 2012), the problem is found in Aisiyah BA Bendo kindergarten where the teacher always teaches introducing the prayer is only told to memorize without practicing the movement according to the taught reading, not demonstrating directly by using "Mukena", the way of delivery is only concentrated on the teacher of the child not given the opportunity to speak and just memorize it so the child becomes bored and saturated. With the current method Early childhood childhood prayer ability can not be developed and consequently the child later difficult to be introduced to prayer, unable to repeat the movement of prayer, difficult to memorize the reading and reluctant to perform the prayer. And in the end the child is not able to perform the worship properly and smoothly. As in research (Kinasih \& Prabowo, 2013) also says almost all schools have incorporated religious lessons into their school curriculum, especially in elementary school (SD). (Kinasih \& Prabowo, 2013) also said that in religious lessons there is a lesson about praying five times, it is not all students can grasp the meaning conveyed by their teachers, because the way they teach is usually only by telling stories.

In this case study, this research was conducted at Pesantren Arafah located in Sungai Penuh district Kerinci Jambi Province. As also school other, where eligious teachers still use markers or gestures of the human body as a medium of learning; this resulted in many emergences of problems for students. This will affect student achievement. A common problem faced by students is that there are still many students who have not been able to achieve satisfactory learning achievement. There are several factors that cause learning achievement is failing one of them is the lack of learning media facilities provided by the teacher or the pesantren. It greatly affects students' learning interest in the material taught by the teacher and the difficulty of the students to remember the material being taught. The lack of enthusiasm of the students in learning is caused by the lack of learning media facilities provided in Arafah Pesantren Sungai Sungai Penuh, so it affects the students' learning interest in understanding, remembering and memorizing the subject matter. In learning material guidance of prayer students difficulty memorizing the subject matter, because the learning media used by teachers is less interesting, so the willingness or motivation of students in learning is reduced. Teachers are more likely to use books, whiteboards and markers as a medium of learning which is still a primary learning medium, so it is not surprising that students tend to be bored, bored and lack of respect for the subject matter of one of the lesson material of prayer guidance.

The learning process of prayer guidance less interesting, because in the complex subject matter most students do not understand the material presented by the teacher. The use of books, whiteboards and markers as a medium of learning makes students tend to feel bored and less interested to follow the learning process is monotonous and does not vary, and the lack of willingness and active participation of students menguasi taught material, so that the learning process was not going well. Pesantren Arafah Sungai Penuh city basically has been using the computer, but not yet optimally utilized in other words the form of presentation of learning materials prayer is still done manually or body movement in the media learning.

The results of this study is to determine the effectiveness of students' ability improvement after utilizing instructional media of Macromedia Flash Professional prayer based instruction 8 in Pesantren Arafah Sungai Penuh city. Based on the above description the authors want to make learning media guidance mandatory prayer for Pesantren Arafah Sungai Penuh city using Macromedia Flash Professional 8. 


\section{Literature Review}

\subsection{Understanding of Multimedia}

Multimedia is a combination of computer and video (Rosch in M. Suyanto, 2005, 20) or Multimedia is generally a combination of three elements, namely voice, image and text (McCormick in M. Suyanto, 2005, 21) or Multimedia combination of at least two media inputs or outputs of data, this medium can be audio (sound, music), animation, video, text, graphics and pictures (Turban et al in M. Suyanto, 2005, 21) or Multimedia is a tool that can create dynamic presentations and interactive that combines text, graphics, animation, audio and video images (Robin and Linda in M. Suyanto, 2005, 21).

\subsection{Understanding of Interactif Media}

According to Seels and Glasgow in Arsyad (2006: 36) suggests that the interactive media is a media delivery system that presents video recording material with computer control to the audience (students) who not only hear and see video and sound, but also provide an active response and response that determines the speed and sequence of representation. The interactive media has an audio-visual element (including animation) and is called interactive because it is designed to involve active user response.

\subsection{Understanding of Learning Method}

According to Roestiyah N.K. in Urip Widodo (2013), teaching methods are also interpreted as teacher techniques to teach or present instructional materials to students in the classroom, so that the lesson can be captured, understood, and used by students well. According to Made Wena in Urip Widodo (2013), a strategy or method of learning means a way or an art to use all learning resources in student learning. Hamdani in Urip Widodo (2013), concluded that the process of teaching and learning is the process of educational interaction between teachers who create the atmosphere learning and students who respond to the teacher's efforts, The types of learning methods can be observed as follows:

\section{a. Lecture Method}

Lectures are a conventional method of learning, lectures if too often used will not be effective. According Suprayekti in Nurhidayati, M. Hum (2011) lecture method needs to be improved in its application by: a. build attraction. b. maximize understanding and memory. c. involving students. $d$. provide reinforcement.

b. Question and answer method

Question and answer method is also a method of conventional learning Question method used by teachers to determine the level of understanding of learners to a problem, According Mulyiningsih in Nurhidayati, M. Hum (2011) there are three questions that need to be known in conveying learning materials, namely: a.pertanyaan focused. b.prompting questions.c .probing question.

c. Recitation Method

Recitation methods are usually used to diagnose the learning progress of learners. The recitation is applied by using the pattern that the teacher asks, the learner responds, then the teacher reacts. Recitation by Gage and Berliner, through Mulyatiningsih in Nurhidayati, M. Hum (2011) is commonly used in review, introduction of new material, checking answers, practices, and checking learners' understanding of the subject matter and ideas.

\section{d. Practice and Drill Methods}

The method of practice is done after the material is learned or the teacher gives demonstration. Drill methods are used when learners are asked to repeat information on specific topics until they can master the topics being taught. Methods of practice and drill are also called methods of practice and practice. The method is directed at repetition (repitition) to help learners have a better understanding and easily recall the information already delivered. 
Discussion method is a method of learning that directs learning to centered on students, achievement of competence in the subject of theory often use the method of discussion so that learners are active and gain knowledge based on the findings themselves. Several methods, from several methods above, the method used for this research are:

1. Question and answer method, caused this method is considered more clear, and more accurate in the discussion of the material so that students easier to understand the lesson delivered so that the results obtained more leverage.

2. The method of recitation, caused this method can know to what extent the ability of students in understanding the discussion of the taught material, so that the ability of students can be more maximized in understanding a material taught.

\section{Research Methods}

In this discussion there are several research methods are:

3.1. Library research (Library Research)

This research is conducted to search, read, and learn to understand the book that has to do with information system of data processing and multimedia used. collecting materials and theories as the basic material related to the issues discussed.

\subsection{Field Research (Field Reseach)}

Field research aims to make observations directly to Pesantren Arafah Sungai Penuh city as well as, studying problems that have to do with this research, in a way.

a. Interview (Interview)

In this technique, the author interviewed the Head of Pesantren and quietly lectured in conducting research into the field by providing questions related to the learning process at Pesantren Arafah as the object of research.

\section{b. Direct Observation (Observation)}

With this technique the authors observe and record carefully and examine the actual situation. With direct observation the author can see the learning process at Pesantren Arafah Kota Sungai Penuh.

\subsection{Laboratory Research (Laboratory Research)}

In this research method by using PC (Personal Computer) to simulate experiments in making a useful application program to help menyasaikan this problem.

The Information System Flow Procedure to be proposed can be described as follows:

a. The teacher presents the material of obligatory prayer to the students by using Interactive Media learning.

b. Then the students receive the material submitted by the teacher by means of interactive media guidance mandatory prayer.

c. Students then understand easily the material that has been delivered. 


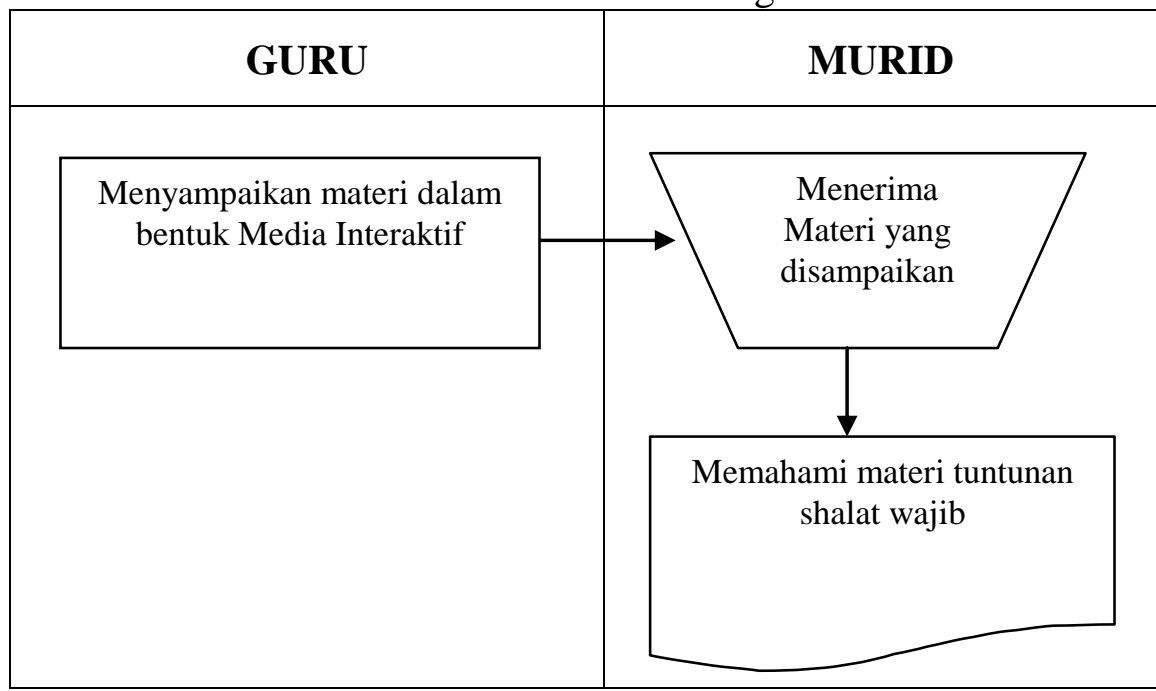

Figure 1: Information System Flow (ASI) Proposed

\section{Results and Discussion}

Initial design or initial design of each menu and sub menu that will be displayed is needed to facilitate the making of applications remembering, understanding and memorizing this mandatory prayer guidance. This initial design will be an early picture in the process of making an animated study of mandatory prayer guidance.

\subsection{Home Page Design}

Home page is the first page before the main menu page, On the home menu home page contains six buttons are the main menu button, how to wudu, prayer hours, profile, settings and exit. The initial design of the menu options page in this application as shown in figure 2 the following:

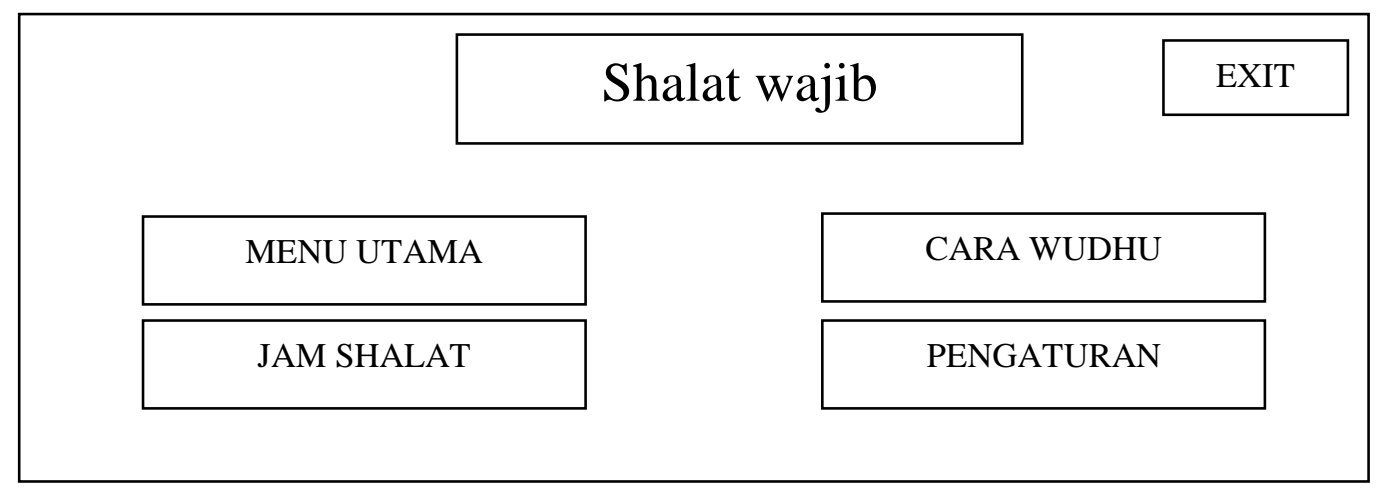

\subsection{Main Menu Design}

This application main menu page consists of six buttons namely dawn prayer, dzuhur prayer, azhar prayer, Maghrib prayer, isya prayer and back. The design as shown in Figure 3 below:

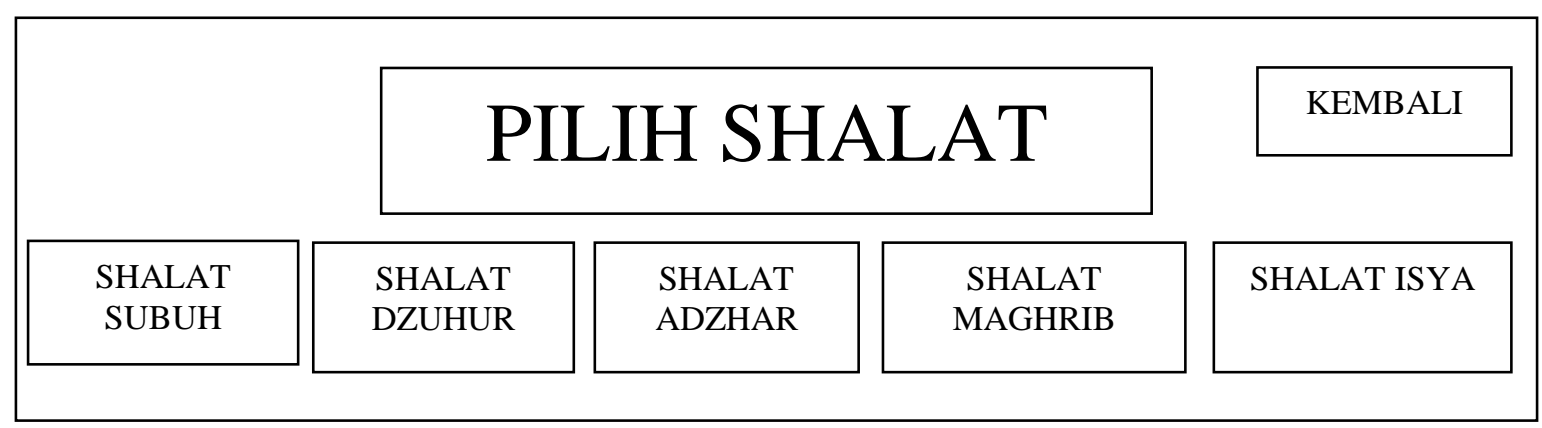

Figure 3 : Main Menu Design 


\subsection{Prayer Menu Design}

This is a menu page selecting a prayer movement consisting of several prayer movements. The design is as shown below:

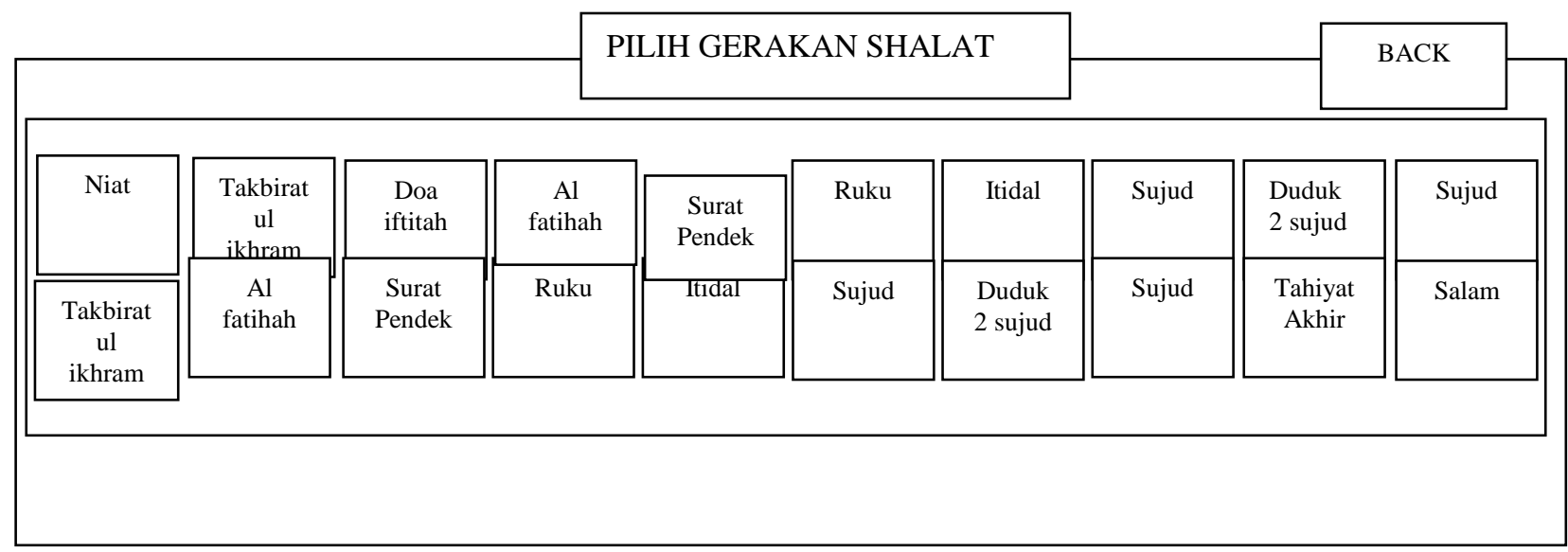

Figure 4: Menu Page Design Select Prayer Movement

1. View in Menu select the movement of prayer in Button of prayer movement This page is a motion menu app made up of three buttons BAHASA ARAB, BAHASA LATIN and KEMBALI. The design is like the following Figure 5:

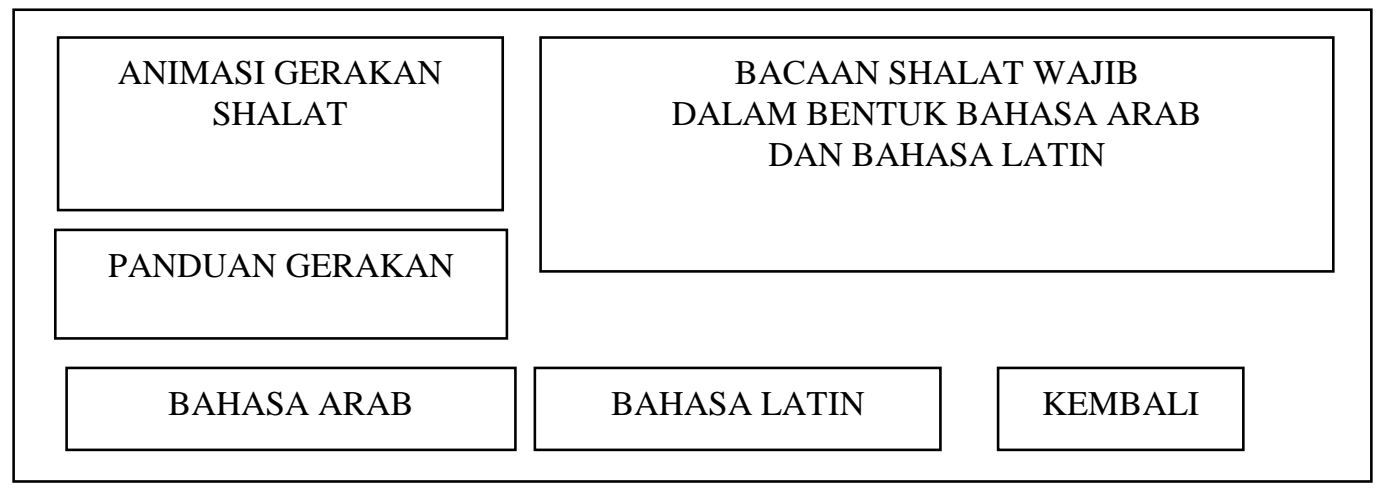

Figure 5: Menu select the movement of prayer

Figure 5: Menu select the movement of prayer in the prayer movement Button 2. Menu Design Procedures Wudu '. The design as shown in Figure 6 below:

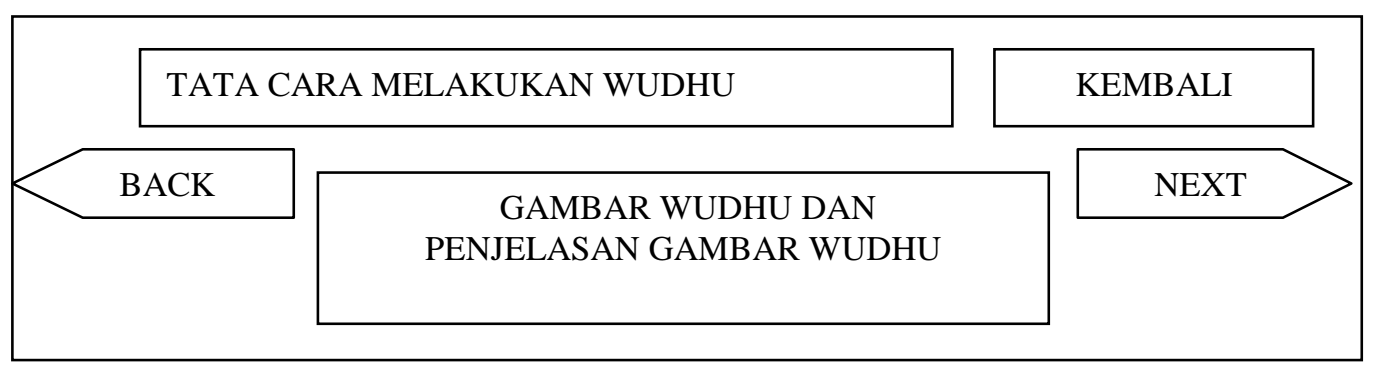

Figure 6: Menu Design Procedures Wudu '

4.4. Menu Design Prayer Time

This application is a prayer clock menu page consists of five buttons namely the morning prayer hour, dzuhur prayer, azhar prayer, maghrib prayer, payer isya. The design as shown in Figure 6 follows: 


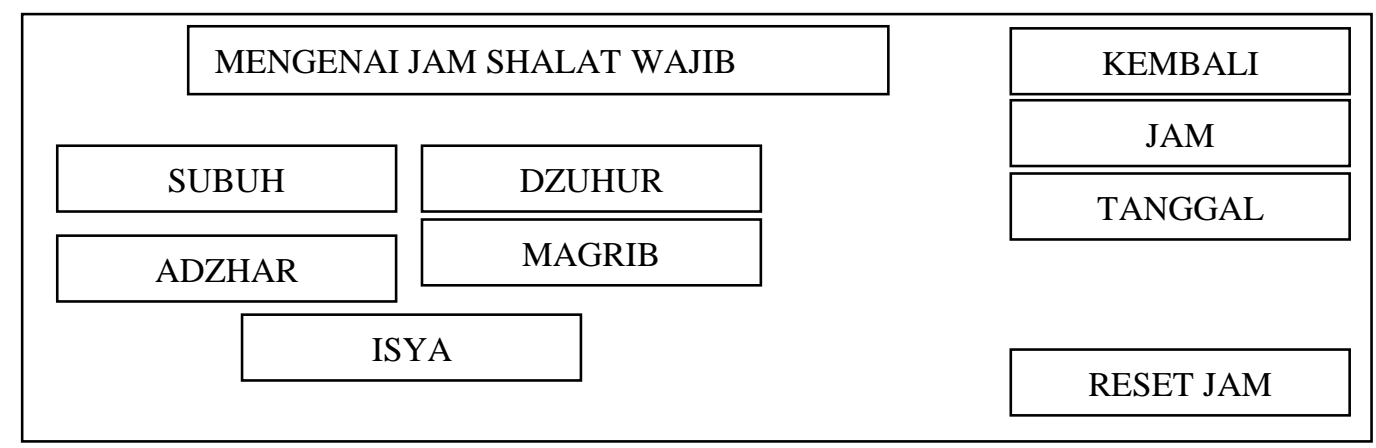

Figure 6 : Menu Design Prayer Time

\subsection{Configuring (Setting) Menu Design}

The settings menu page is the page to set the size of the display screen in the application. The initial design of the settings menu page can be viewed as shown in Figure 7 below:

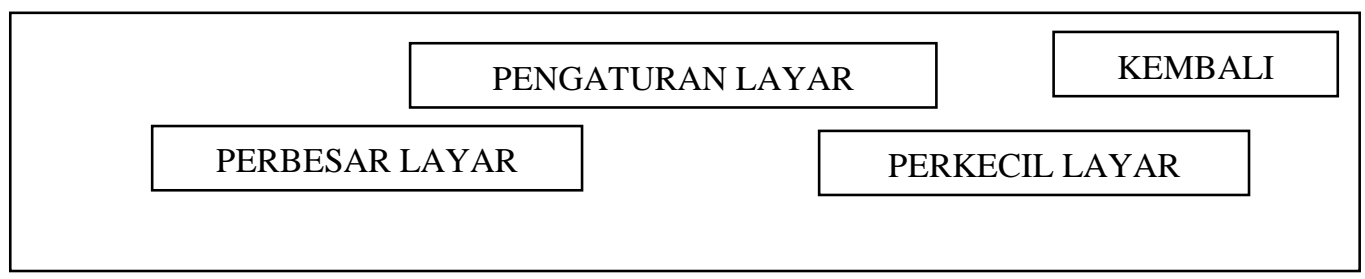

Figure 7: Configuring(Setting) Menu Design

\subsection{Menu design Guide movement}

The menu page on the guides of the Salat movement animation, The initial design of the movement guide menu page can be viewed as shown in Figure 8 below:

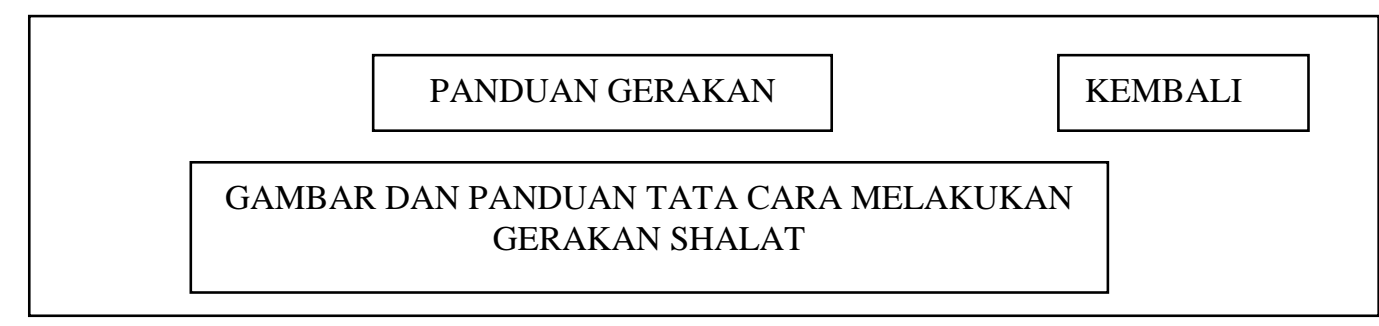

Figure 8 : Menu design Guide movement

\subsection{Exit Menu Design}

The exit menu page, a page to exit or return from the application The initial design of the exit menu page can be viewed as shown in the following 9

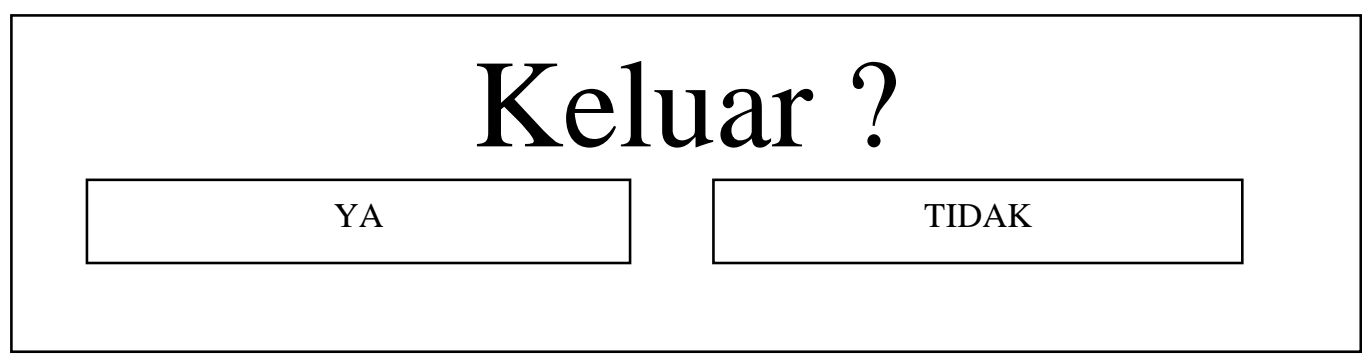

Figure 9. Exit Menu Design View

\subsection{Implementation of System Design}


After performing a series of stage planning, analysis and design then obtained an application in accordance with the design and analysis before. Application of this mandatory prayer guidance in the expectation needs to be done a test to fit the design, design and purpose of the subject matter before.

\section{a. Home Page}

The home page is the page that appears first before the Main Menu page, on this page also contains the title of the app, main menu, prayer hours, how to wudu, profile, settings and exit. Home page will appear immediately after

run.

The home view of the mandatory prayer application can be seen in Figure 10 as follows:

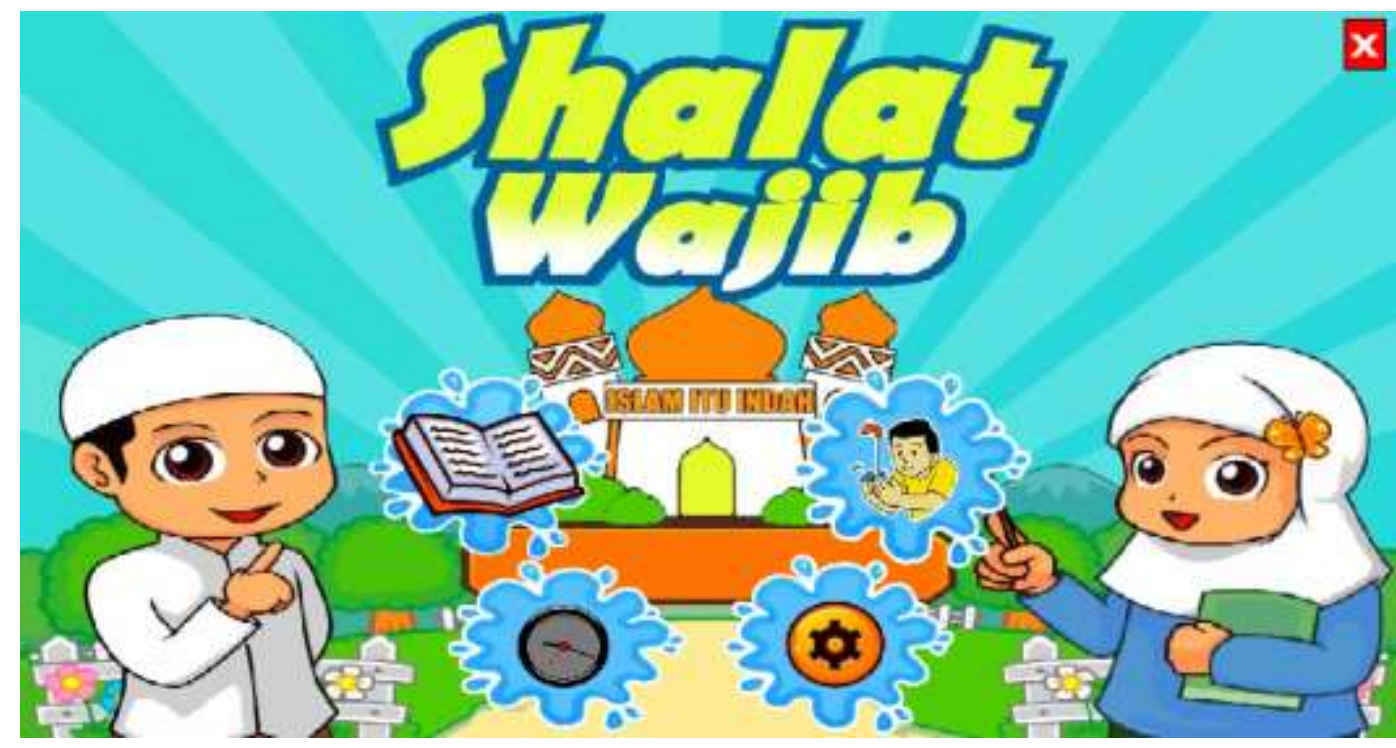

Figure 10 : Home Page View

\section{b. Main Menu Page}

This main menu page contains a mandatory prayer menu. Menu selection is done by click menu available on the main menu, then display the page according to the choice of button that is clicked. Main page view of this mandatory prayer guidance can be seen in Figure 11 as follows:

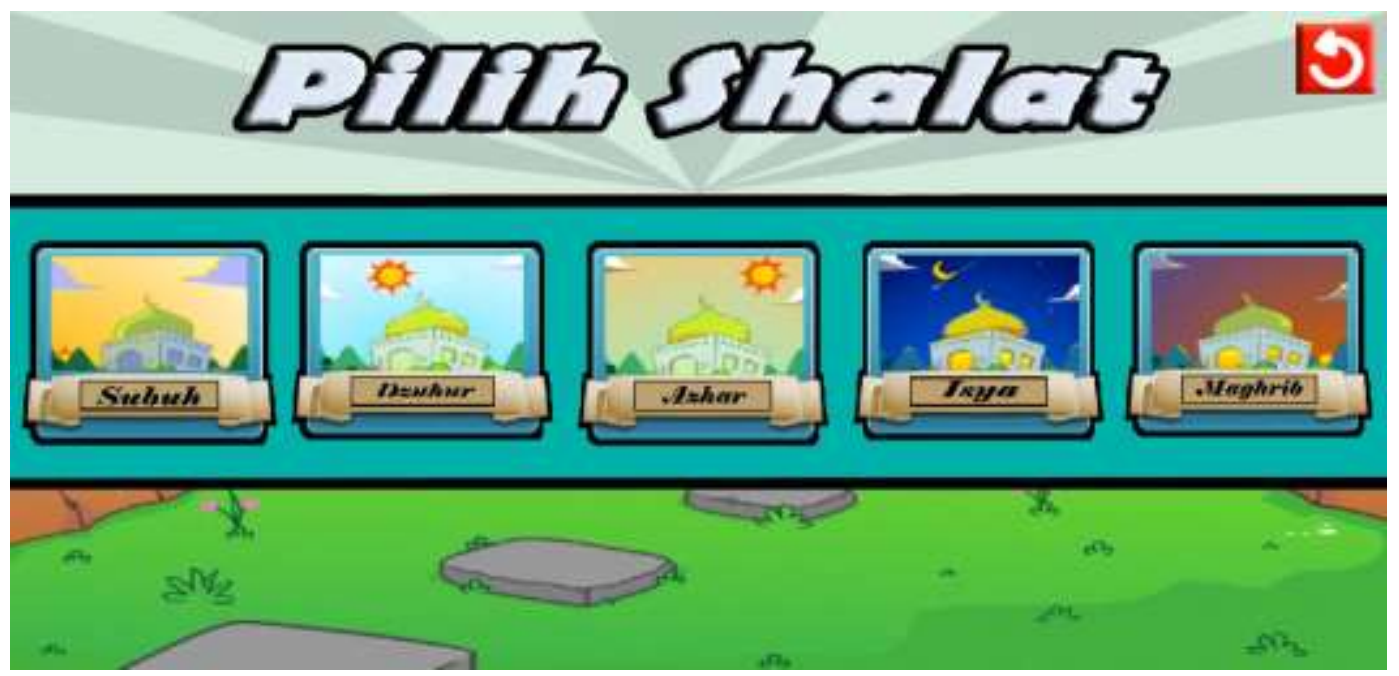

Figure 11 : Main Menu View

\section{c. Choose Menu Page of prayer movement}

This page contains a menu select the movement of prayers that are displayed in the main sub menu, select the movement can be seen in Figure 12 below: 


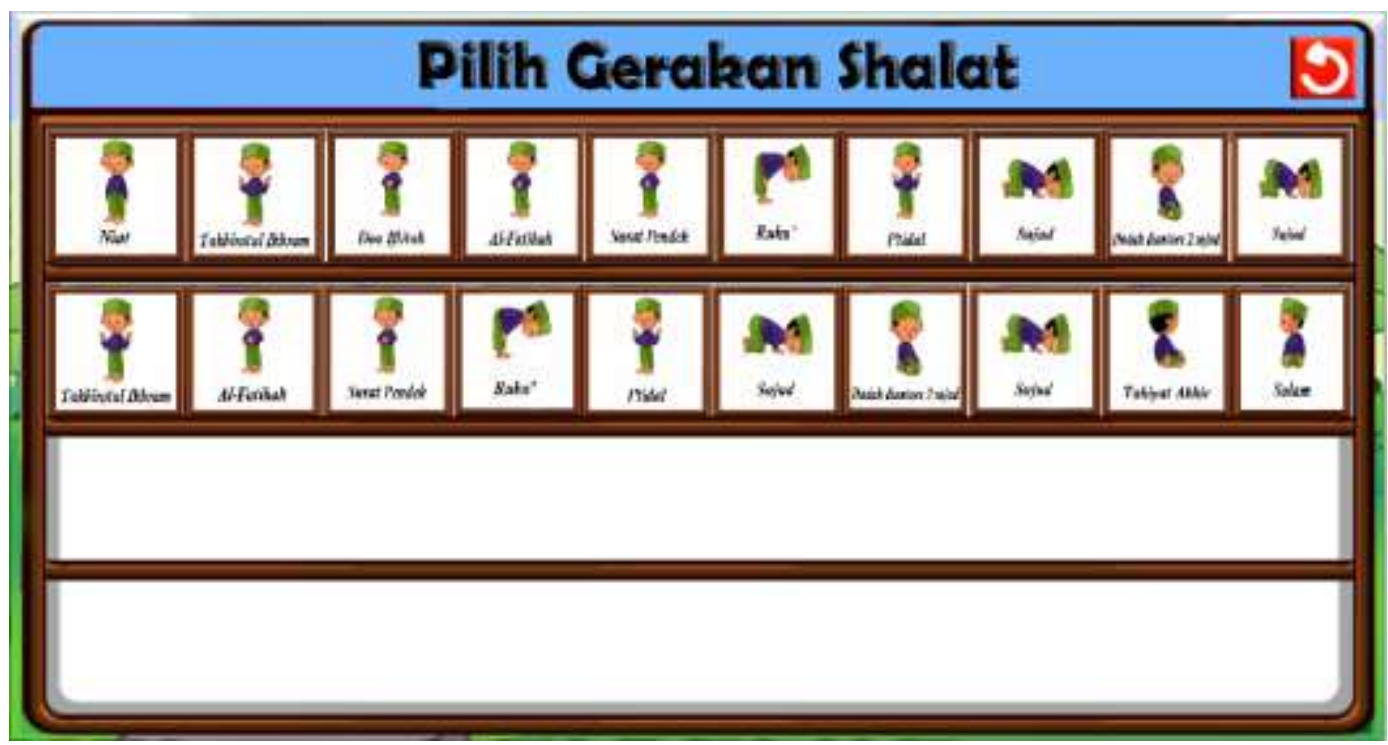

Figure 12 : Choose Menu Page of prayer movement view

d. View In Menu select the movement of prayer in Button select prayer movement

This page contains readings and movements of prayer that are translated in Arabic and Latin form as a whole and in other dilayer displays can be seen in the following 13 pictures:

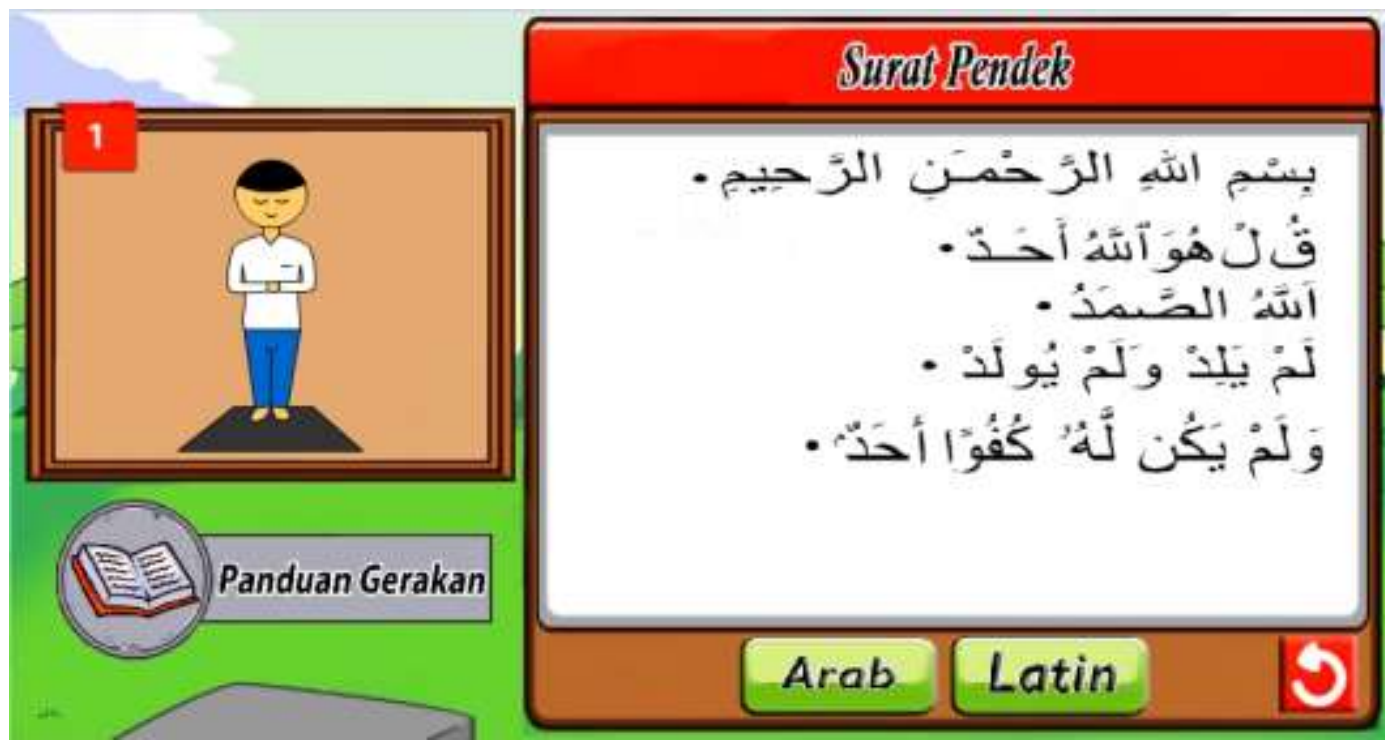

Figure 13: View In Menu select the movement of prayer

\subsection{Wudhu' Pocedure Menu View}

This page contains the complete steps of taking ablution which are displayed in the other layers of view can be seen in the following 14 pictures: 


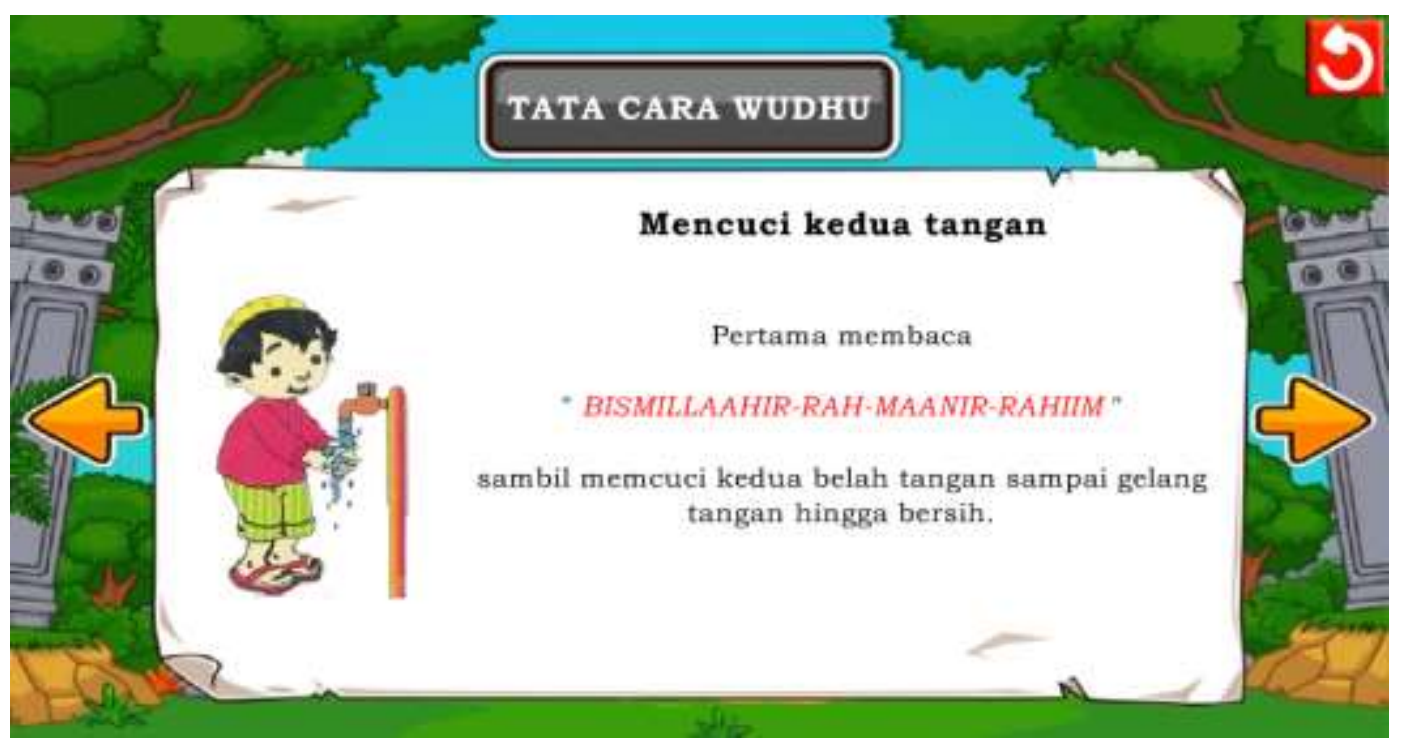

Figure 14 : Ablution guidance View

\section{a. Exit Menu View}

This page contains the exit menu that is displayed in another layer, the menu selection is done by clicking if the button is selected yes then the application will exit, if not then the application will return to the home menu view can be seen on the picture 15 below:

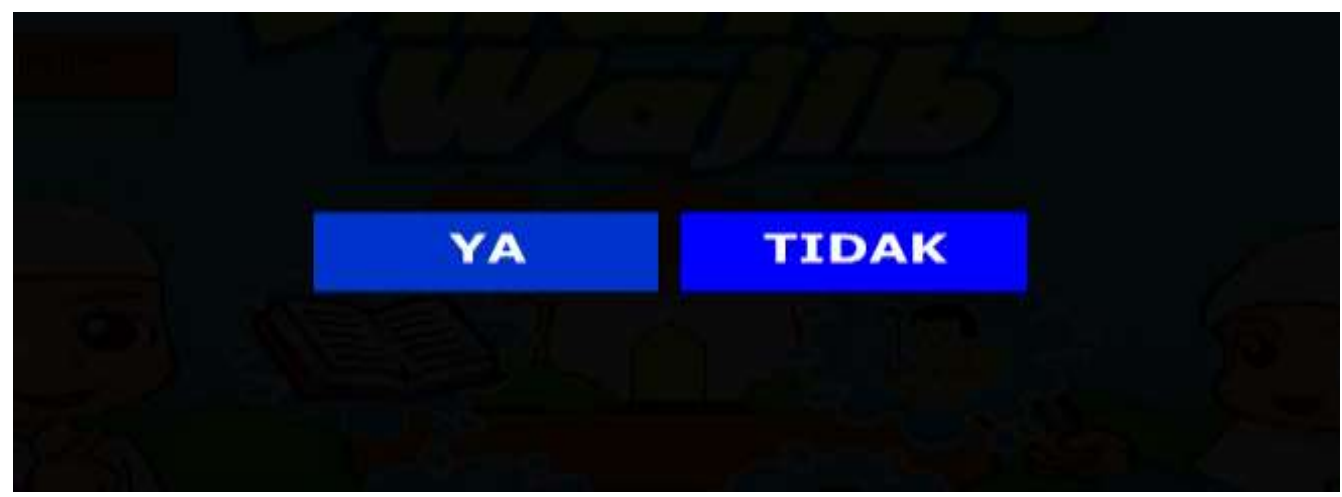

Figure 15 : Exit Menu View

\section{b. Setting Menu View}

This settings menu page contains a menu of screen settings. Selection of the menu done by melakukan with the menu click available on the settings menu, to then display the page according to the choice of buttons on the click. Page view The application menu of this mandatory prayer guidance can be seen in Figure 16 as follows: 


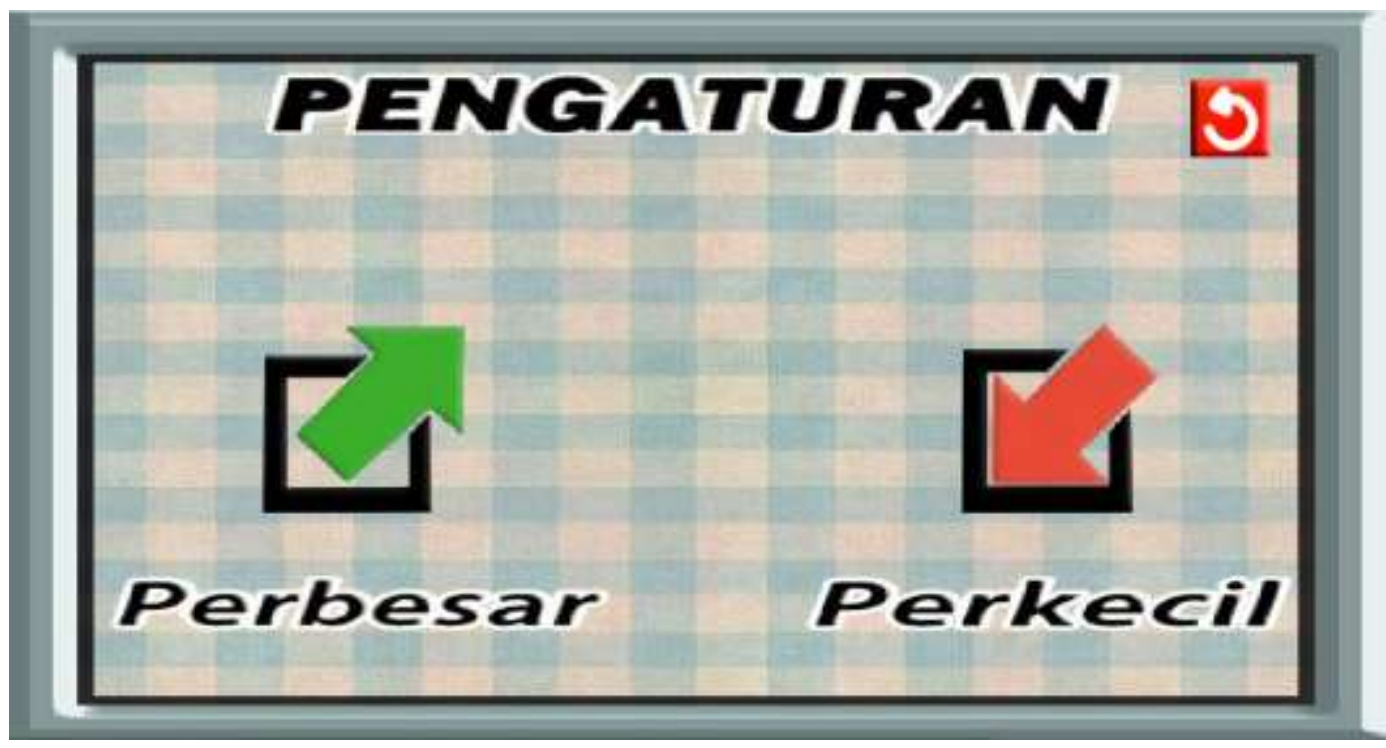

Figure 16 : Setting Menu View

\section{c. Prayer Time Menu View}

This page contains a prayer clock menu that is displayed in another layer, the clock setting is done by entering the prayer hour, if the hour of prayer is set then the clock will issue the voice on the hour and minute that has been determined, the clock display can be seen in the Figure 17 below:

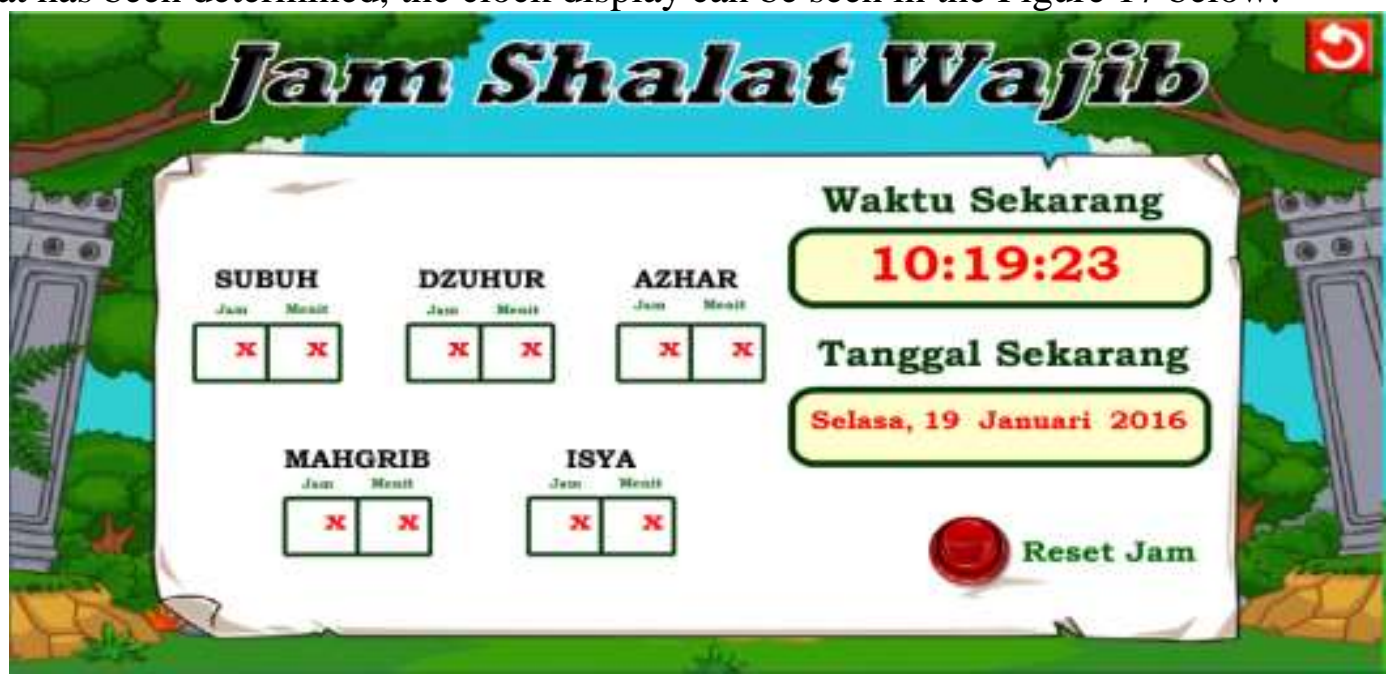

Figure 17 : Prayer Time Menu View

\section{d. Guidance Movement Menu View}

This page contains a menu of prayer movement guides, which is the page that contains instructions for performing the prayer movement, the view of the movement guide menu can be seen in Figure 18 below:

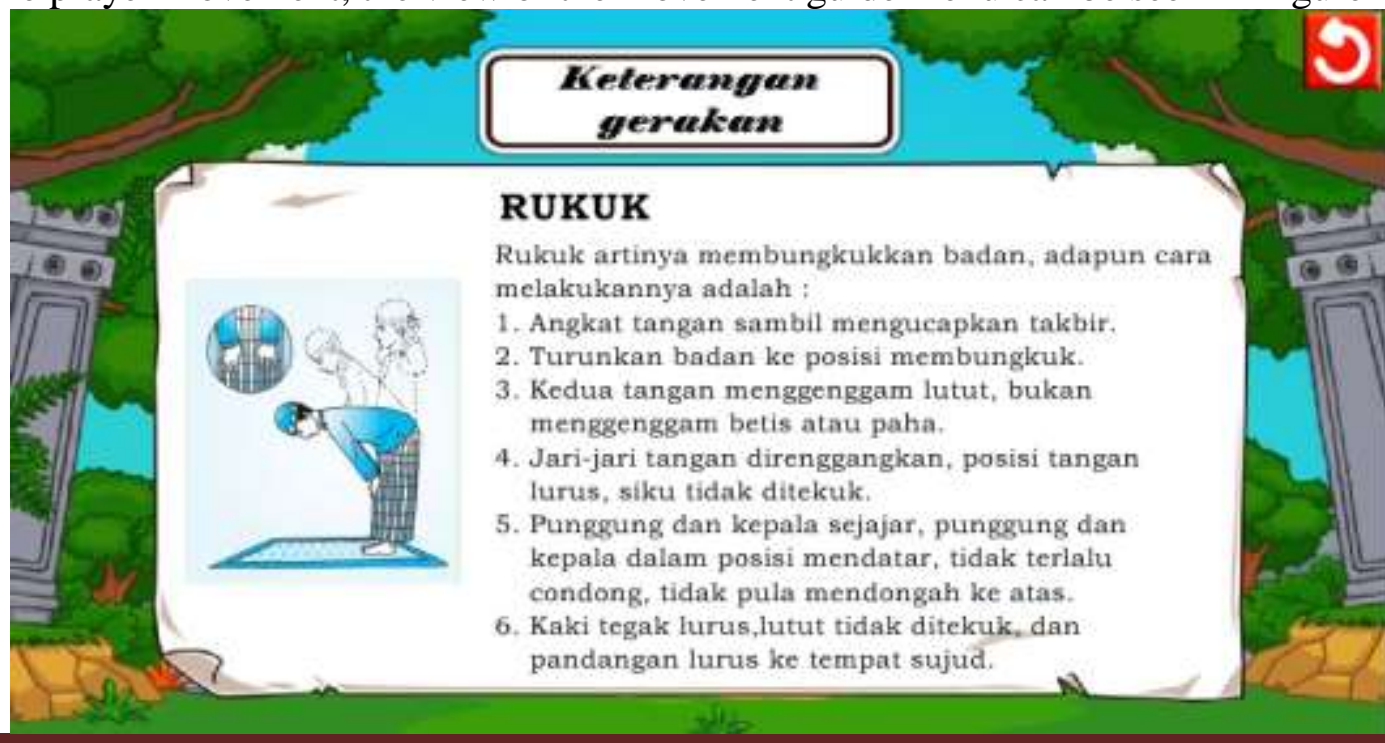




\section{Figure 18 : Guidance Movement Menu View}

\section{Conclusion}

Based on the analysis that has been done that has been obtained during the design and manufacture and implementation of the results of mandatory prayer application for Pesantren Arafah Kota Sungai Penuh, it can be concluded in:

1. The design of Macromedia Flash based prayer applications is built for interactive learning for students at Arafah Pesantren, making it easier to understand and study the movement and prayer readings correctly, and improve students' ability to understand the lessons maximally.

2. Designed in the form of a more attractive and more detailed, so that this interactive media can improve student learning outcomes are good and can learn how to perform prayers correctly.

3. With this media, students' problems in understanding the prayer guidance can be overcome.

\section{Acknowledgment}

The author would like to thank the Amal Bakti Mukmin Foundation (ALBANI) Padang who has provided support in the form of material and spirituil, so that this research can be completed in a timely and appropriate manner.

\section{References:}

[1] AJ Hanif, Fatta. 2007. Analisa \& Perancangan Sistem Informasi. Andi. Yogyakarta

[2] Kusrini. 2007. Strategi Perancangan dan Pengolahan Basis Data. Andi Yogyakarta

[3] Fachrurrazi, S., \& Afwadi, S. (2010). PERMAINAN PERAN (ROLE PLAY) UNTUK PEMBELAJARAN SHALAT. TECHSI: Jurnal Penelitian Teknik Informatika.

[4] Hidayati, E. (2012). Peningkatan Kemampuan Shalat Anak Usia Dini Melalui Metode Modelling.

[5] Kinasih, D., \& Prabowo, N. A. (2013). Pembuatan Media Pembelajaran Interaktif Shalat Fardhu Lima Waktu. Sentra Penelitian Engineering Dan Edukasi, 5(4), 52-58. Retrieved from ijns.org

[6] Liu, M., Toprac, P., \& Yuen, T. T. (2009). What Factors Make a Multimedia Learning Environment Engaging:A Case Study. Retrieved [January 2012], from Jabba.edb.utexas.edu: jabba.edb.utexas.edu/IT/new/LiuTopracYuen.pdf.

[7] Lubis, M. A., Nordin, N., Embi, M. A., Daud, M. Y., Din, R., Karim, A., \& Al-Ganzouri, F. M. (2013). Development and evaluation of a multimedia software (smart solat) for j-QAF program for malaysian primary schools. Research Journal of Applied Sciences. https://doi.org/10.3923/rjasci.2013.5.8

[8] Matz, L. (2010, July 16). Teaching Method. Retrieved November 27, 2011, from cbs.dk/en/: http://www.cbs.dk/en/Continuing- Education/Menu/Teaching-Method

[9] NORA BT MAMAT, 2008, LEARNING SOLAT FOR CHILDREN 6 TO 12 YEARS OLD USING 2D ANIMATION, Thesis Sarjana Muda (PSM) Universiti Teknikal Malaka Malaysia

[10]Nurhidayati. 2011. Metode Pembelajaran Interaktif. Seminar Pembelajaran: Depok.

[11]Ramadian Fetty, Jayantha Murti. 2004. Modul Pratikum Rekayasa Perangkat lunak. Software Engineering Laboratory.

[12]Rijayana, Iwan. 2007. Aplikasi Pembelajaran Interaktif Tuntunan Tata cara Shalat Wajib.Seminar Nasional, Semarang.

[13]Suyanto M. 2005. Alat Untuk Meningkatkan Keunggulan Bersaing: Andi Yogyakarta.

[14]Wahyono, Teguh. 2006, Animasi Dengan Macromedia Flash 8. PT Elex Media Kompotido Gramedia: Jakarta.

[15]Winata Edgar, Setiawan Johan. 2013. Analisa dan perancangan prototype Aplikasi Tracking bis Universitas Multimedia. Universitas Nusantara: Tanggerang.

[16]Yesi Rudyana dan Aditya Rahman Yani, MULTIMEDIA INTERAKTIF BELAJAR ADAB WUDHU, SHALAT DAN DOA SETELAH SHALAT, Desain Komunikasi Visual Fakultas Teknik Sipil dan Perencanaan Universitas Pembangunan Nasional "Veteran" Jawa Timur Jl. Raya Rungkut Madya Gunung Anyar Surabaya 60294, CREATEVITAS Vol.3, No.2, Juli 2014:391-403 


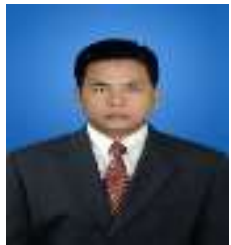

Sotar, he is received the Bachelor 2005 in Islamic Law at IAIN Imam Bonjol Padang Indonesia, and Master of Islamic Law from IAIN Imam Bonjol Padang, Indonesia, in 2011. $\mathrm{He}$ has been working as Lecturer at STMIK Indonesia Padang from 2011 in the Dept. of Islamic Education, STMIK Indonesia Padang. his research interests on Islamic Law, Worship, Ccomparative Law and Madhhab.

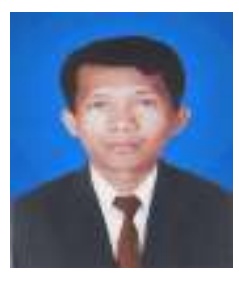

Suardinata, he is received the Diploma III 1999 in Information Management at AMIK Riau, Indonesia, Bachelor Degree in Information Engineering from STMIK Riau, Indonesia, and Master Degree in Information Technology from Universitas Putra Indonesia, Padang, Indonesia. Currently he is a Ph.D. student in the Dept. of Computer System and Communication, Faculty of Computer Science and Information System, University Teknologi Malaysia, Johor Bahru Malaysia. He has been working as Lecturer at STMIK Indonesia Padang from 2005 in the Dept. of Computer Science and Information Systems, STMIK Indonesia Padang. His research interests include, Multimedia and Voice over IP network, Network Security, Traffic Engineering and Quality of Service issues in IP networks, Wireless Ad-Hoc Networks, and Distributed Systems.

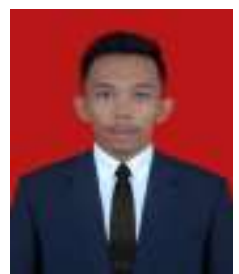

Randi Satia Irawan, he is received Diploma Degree in Informatic Management at AMIK Depati Penuh Sungai Penuh in 2014 year, Bachelor Degree in Information system in 2016 at STMIK Indonesa Padang, Indonesia, he has working as multimedia practicer and instructor freelance at any schools in Sungai Penuh. His research interest in multimedia design and creatin 